\title{
The Establishment and Exploration of Diversified High Level Engineering Practice Education Platform
}

\author{
Wang Xi, Liu Jian*, Zhang Xiaojun, Xue Zhengkun \\ School of Mechanical Engineering and Automation, University of Science and Technology Liaoning, Anshan, China \\ Email address: \\ wx1870@yeah.com (Wang Xi), 13941214957@163.com (Liu Jian) \\ ${ }^{*}$ Corresponding author
}

To cite this article:

Wang Xi, Liu Jian, Zhang Xiaojun, Xue Zhengkun. The Establishment and Exploration of Diversified High Level Engineering Practice Education Platform. Higher Education Research. Vol. 6, No. 5, 2021, pp. 138-141. doi: 10.11648/j.her.20210605.17

Received: August 26, 2021; Accepted: September 11, 2021; Published: September 23, 2021

\begin{abstract}
Practical teaching is not only an important link in the process of cultivating applied talents, but also an important means to improve students' engineering application ability and innovation ability. In order to cultivate high-level application-oriented talents, aiming at the current lack of digital and intelligent knowledge among college students and the lack of "personalized" specialty, this research group adheres to engineering practice education as the main line, aims at cultivating application-oriented talents in engineering, and features in improving students' innovation ability. With the construction of new curriculum system, new innovation and entrepreneurship system and new practical teaching system as the core, it has built a diversified high-level engineering education practice platform integrating digital analysis and simulation, intelligent manufacturing and testing, and virtual simulation of production process. Explore its own distinctive characteristics of high-level application-oriented talent training new mode and new ways, cultivate students' innovative thinking and the ability to solve practical problems, in mechanical design ability has been rapidly improved, become an expert in design. At the same time, the level of intelligent manufacturing and intelligent detection has been improved, and personalized high-end talents with both professional knowledge and digital and intelligent knowledge have been refined to meet the social demand for such technical compound talents.
\end{abstract}

Keywords: Engineering Education Practice Platform, Engineering Practice, Individuation, Applied Talents

\section{Introduction}

There are 8 million college graduates in China every year, but the individualization is not outstanding, and there is a shortage of specialized personnel. The society is in urgent need of high-end talents in mechanical design, intelligent manufacturing and intelligent testing. In order to solve the current shortage of talents in this field in China, it is necessary to carry out targeted training according to students' respective interests and specialties, so as to truly cultivate talents suitable for social needs in this aspect.

Therefore, the School of Mechanical Engineering and Automation has established a diversified and high-level engineering education and practice platform [1, 2]. The purpose is to create high-end talents in mechanical design, intelligent manufacturing and intelligent testing, and solve the problem of social demand for talents in this aspect.

In order to highlight the cultivation of students' engineering practice and application ability, with the reform of talent training plan as the core, the construction of new curriculum system, new innovation and entrepreneurship system, and new practice teaching system as the guarantee, and with engineering education as the main line, we focus on improving students' engineering awareness, engineering quality and engineering practice and application ability [3, 4]. On this basis, we will establish a diversified high-level engineering education practice platform to improve students' practical and applied ability, and explore a new mode and new way of cultivating high-level applied talents with distinctive characteristics, so that students can quickly improve their abilities in mechanical design and become experts in design. At the same time, the knowledge and ability of intelligent manufacturing and intelligent detection has been improved to meet the needs of the society for personalized talents.

In the process of cultivating students, we always regard the 
cultivation of engineering practice ability as the first task, and take root in the hearts of students. Build a high-level engineering education practice platform $[5,6]$, and then create personalized talents, to meet the social demand for talents in this aspect. The high-level training platform will be used to train students according to their own interests and hobbies.

Those who are interested in digital design will be specially trained for design talents, and who are interested in intelligent manufacturing and intelligent detection and diagnosis direction will be trained for intelligent detection and manufacturing talents. The students cultivated in this way are not mediocre but few but excellent high-end talents.

The block diagram of engineering education practice platform is shown in Figure 1.

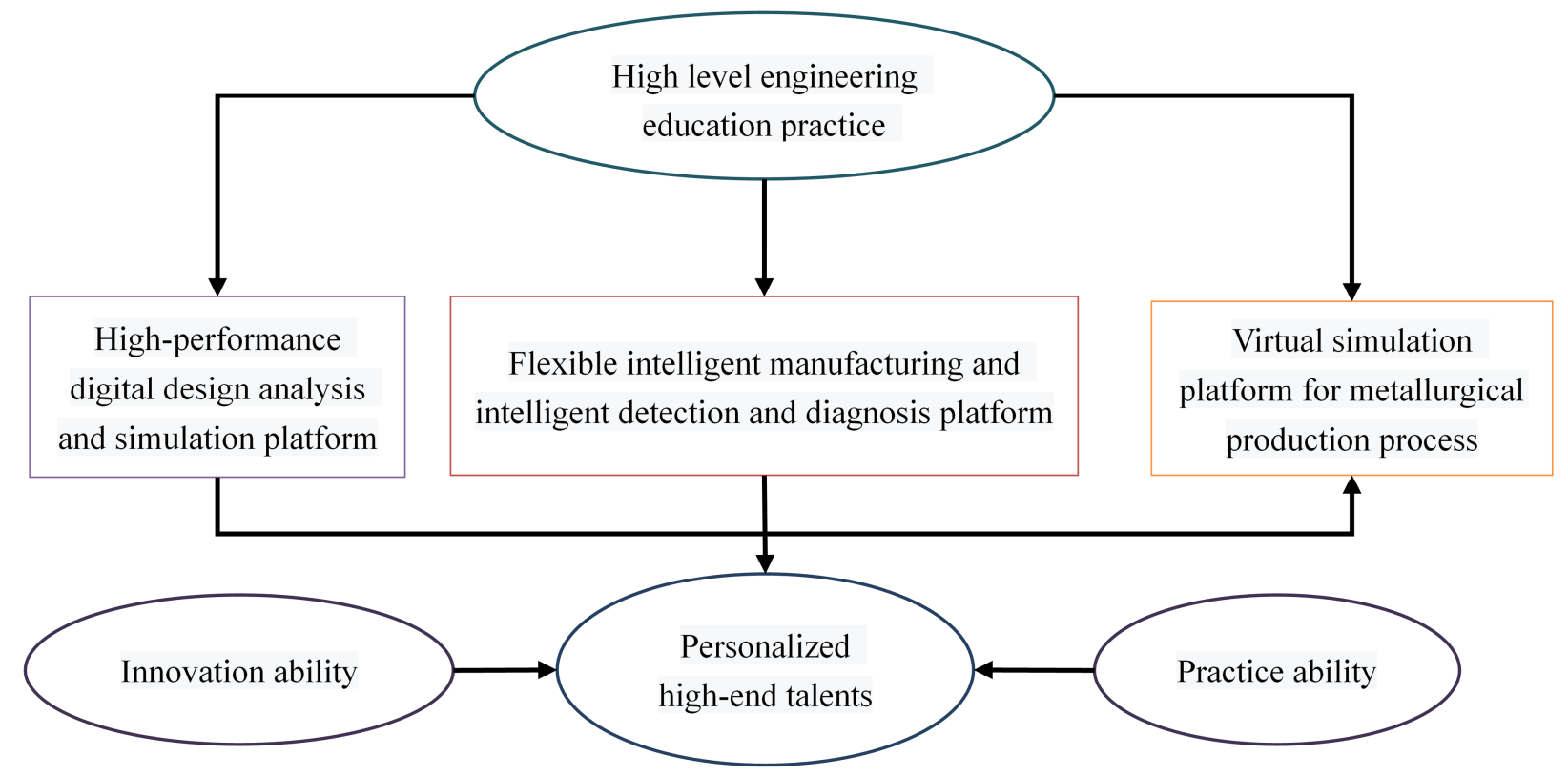

Figure 1. Block diagram of high level engineering practice education platform of Mechanical College.

\section{Diversified High-level Engineering Education Practice Platform}

\subsection{Create High Performance Digital Design Analysis and Simulation Platform}

Create a high-performance digital design analysis and simulation platform, which can focus on improving students' engineering design, finite element analysis, optimization design and simulation capabilities [7, 8].

It is made of high-performance dedicated graphics workstation and high-precision coordinate measuring instrument and engineering computing softwares, which have powerful data operation, complex modeling and graphics processing capabilities. It can carry out large-scale engineering design, component modeling, optimization design, finite element analysis, simulation and reverse engineering and other professional fields. It provides a high-performance computer-aided design platform for students to carry out scientific research, engineering design and university-enterprise integration innovation. This platform can greatly improve design and computing efficiency and product quality. At the same time, SolidWorks, mechanical design and other extracurricular certification training are carried out in the education of students, [9-10] so that students' engineering practice and design application ability can be greatly improved, and special talents in need of the society can be cultivated.

\subsection{Create Intelligent Detection and Diagnosis and Flexible Intelligent Manufacturing Platform}

Create flexible intelligent manufacturing and intelligent detection and diagnosis platform, focus on improving students' intelligent machining and detection and diagnosis level.

1. Flexible intelligent manufacturing platform [11] is a high starting point practice platform established by three axis, four axis and five axis open numerical control system. The whole is through the robot to connect each device together, forming a complete closed loop system. Using the flexible intelligent manufacturing platform to carry out numerical control machining skills training for students to cultivate the characteristics of individuation. Students can also form interest groups to work in factories, realizing the organic combination of theory and practice.

2. Intelligent detection and diagnosis platform is a high-level platform jointly established with Beijing Measurement and Control Research Institute, which is also in a leading position in China. Students develop technical skills through participating in teachers' research projects and entering factories for practical learning. 


\subsection{Build Metallurgical Production Process Virtual Simulation Platform}

Set up virtual simulation platform of metallurgical production process. To achieve the purpose of understanding and mastering the whole process of production and performance parameters of metallurgical enterprises in school.

Developed a high-level virtual simulation platform of "Production lines for iron making, steel making, plate rolling and related main equipment", which filled the domestic blank and further enriched the centralized training links. Under the guidance of the core thought of "based on the characteristics of metallurgy, facing the production line", a new concept of cultivating high-level applied talents with "outstanding innovative spirit and strong practical ability" has been established [12]. It lays the foundation and points out the direction for cultivating applied and innovative talents to adapt to the current supply-side reform of colleges and universities. At present, it has cultivated a large number of high-quality application-oriented excellent graduates adapted to the metallurgical production line, which has been highly evaluated by domestic and foreign peers.

\section{Reform Teaching Practice Link}

In addition to creating a diversified and high-level engineering education practice platform, "entrepreneurship training" and "comprehensive innovation and entrepreneurship design" are also newly added. Students can set up a virtual start-up company to complete engineering scheme design, engineering budget quotation, business plan, bidding documents and other training according to the actual enterprise. The graduation internship and design of students have adopted "Double tutorial system for enterprises and schools". The topics selected for graduation design are 100\% practical topics produced by enterprises. The mentors and students can also jointly research and develop enterprise problems, which will lay a solid foundation for students' future entrepreneurship or employment. Through the high integration of school and enterprise, enterprise practice adopts multi-level practical training mode of large-scale state-owned enterprises, small and medium-sized enterprises, private enterprises and other enterprises, so as to create an engineering practice base jointly built by school and enterprise that is based on teaching and closely combined with industrialization to meet production requirements and integrates "innovation, efficiency, entrepreneurship and achievement" [13].

\section{Practical Effect}

The school of Mechanical Engineering in our university has made great contributions to the national metallurgical machinery industry by persisting in the reform and practice of application-oriented personnel training mode for many years.

We actively encourage students to participate in extracurricular innovative academic activities and have achieved fruitful results [14]. 7 successively to guide the national college students' innovative entrepreneurial projects, 10 provincial innovative entrepreneurial projects, and guide students to take part in China, Japan and South Korea international engineering creative design competition silver medal for 3 times, take part in all kinds of mechanical innovation contest, won two 1 item of national first prize, second prize, first prize at the provincial level eight, the second prize three, students published three papers of science and technology, One of them was included in EI, reflecting the achievements of teaching reform.

At the same time, the project team members actively carried out teaching reform research work around the subject, and won a provincial first prize and a university second prize for teaching reform achievements. It has applied for 2 provincial education reform projects and 2 school-level teaching materials projects. 2 provincial education reform projects and 10 university-level teaching reform projects have been completed. Completed two sets of self-made equipment and published 6 teaching reform papers; 3 invention patents and 8 utility model patents have been approved, which fully reflects the effect of teaching reform.

\section{Conclusion}

With the continuous development of The Times, the new era of digitalization and intelligence now requires higher-end talents. Aiming at students' interests and specialties, it is an urgent task for colleges and universities to cultivate new technical compound talents with more technical and professional personalities. The research group provides a beneficial idea and reference for solving this problem by creating a diversified and high-level engineering education practice platform. Although the outbreak of the epidemic has affected the normal teaching order of the school, it has provided opportunities for the construction of engineering education practice platform. Colleges and universities will pay more attention to the construction of on-campus practice platform, in order to solve the disconnection between curriculum content and social practice content, learning ability and practice ability, teaching method and practice and other problems [15]. The most important thing is that under the platform of high-level engineering education practice, students' specialization, digitalization, intelligent innovation and practical ability will be greatly improved.

\section{Acknowledgements}

1.2020, University of Science and Technology Liaoning, Teaching reform research project: "Creating a High-level Engineering Education Practice Platform and Creating personalized high-end Talents" (XJGBZ202019).

2.2018, University of Science and Technology Liaoning, The key project of innovation and entrepreneurship education and teaching research: the construction and practice of the carrier of innovation and entrepreneurship education with the focus of "three kinds of different competitions, training 
methods and combination modes".

3.2016 Liaoning provincial undergraduate education reform project general project "exploration on the cultivation mode of mechanical innovation and entrepreneurship talents based on practice innovation" (Liaoning Education development [2016. 23]).

\section{References}

[1] CAI Weiguo. Exploration and Practice of the Construction of innovation and Entrepreneurship Talents Training Platform for Mechanical Power majors [J]. Journal of Higher Education, 2018 (16): 18-20+23.

[2] He Tusheng. Construction of practical teaching system of materials science and Engineering major in local undergraduate universities [J]. Journal of Higher Education, 2019 (2): 56-58.

[3] Luo Xiaowen. Research on the Innovation of Applied Talents Training Mode in Local Undergraduate Universities [D]. China West Normal University, 2018.

[4] Wang Peng. Research on Practical Teaching System of Application-oriented Undergraduate Universities under the Background of University Transformation [D]. Xi 'an University of Architecture and Technology, 2017.

[5] Yang Qiu. Research on the Status quo of Practical Teaching and Operation Mechanism of Preschool Education Undergraduate Major in Application-oriented Universities [D]. Chongqing Normal University, 2017.

[6] Zhao Jing. Practice Research on Innovative Talents Training in Chinese Universities [D]. China University of Geosciences, 2019.

[7] Qiao Zuqin. Construction of innovation and entrepreneurship Practice platform for college Students in materials discipline [J]. Journal of Higher Education, 2017 (23): 28-30.
[8] Lu Jie. A Study on the Cultivation mode of Innovative and entrepreneurial talents in materials science: A case study of The College of Materials Science and Engineering, Fuzhou University [J]. Innovation and entrepreneurship education, 2016, 7 (03): 102-104.

[9] Su Wenxue, Jiang Na, Wu Hengtao. Construction of Virtual Simulation Practice Teaching Mode guided by innovation Ability Cultivation: A case study of Navigation graduate Students [J]. Contemporary Educational Practice and Teaching Research, 2020 (12): 220-221.

[10] Dong Mingliang. Research on the Cultivation of Innovation Ability of Mechanical Professionals [J]. Science and Technology Economic Market, 2015 (11): 234.

[11] Hu Peng, Shi Ying, JIANG Ying. Construction of experimental platform and course construction around intelligent manufacturing. Modernization of Education, 2018, 005 (051): 192-193.

[12] Zhang Hongtian. Exploration and Practice of Building An Open Practice Teaching System to Cultivate Engineering Application-oriented Talents [J]. Chinese University Teaching, 2011 (08): 73-76.

[13] Liu Mengqin, Kuang Daizhi, Feng Yonglan, Zhang Fuxing, Wang Jianqiu, Xu Zhifeng, Tang Siping. Building a diversified practice teaching system with innovation ability cultivation as the core [J]. Laboratory research and exploration, 2014, 33 (03): 189-193.

[14] Wang Xi, Zhang Xiaojun, Liu Jian, Li Yuan. Construction of Innovative Talent Training Mode of "Three Competitions, Three Trainings and Three Combinations" for Mechanical Major [J]. China Metallurgical Education, 2017 (06): 61-63.

[15] Dong Weiwei, Li Guangchun, Piao Chunxiang, Liang Yunjiang, Feng Jian. Construction of virtual Simulation Platform system based on engineering innovative talent Training [J]. Education and Teaching Forum, 2020 (39): 389-390. 